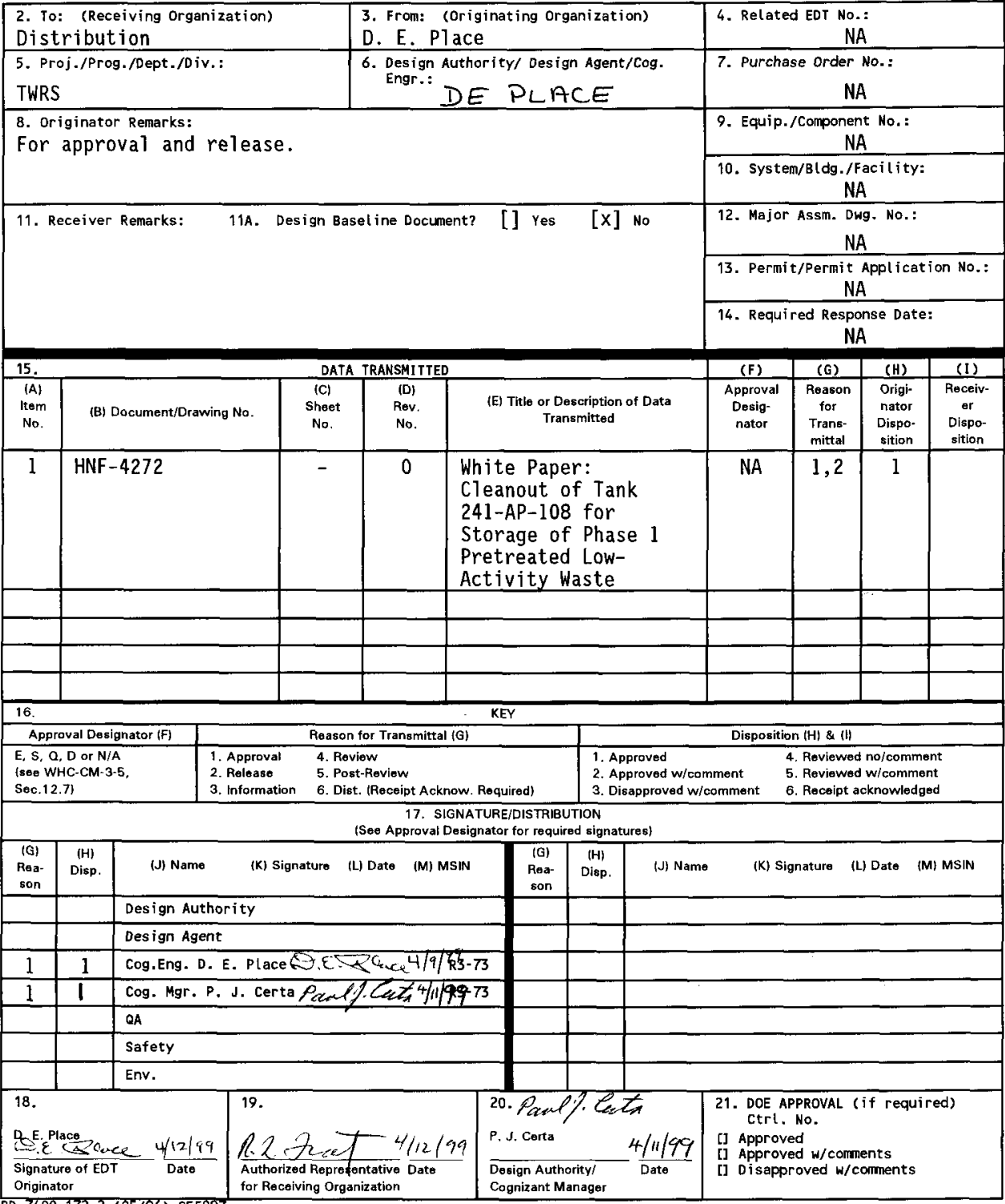

BD-7400-172-2 (05/96) GEF097 
HNF-4272, Rev. 0

\section{White Paper: Cleanout of Tank 241-AP-108 for Storage of Phase 1 Pretreated Low-Activity Waste}

D. E. Place

Cogema Engineering Corporation, Richland, WA 99352

U.S. Department of Energy Contract DE-AC06-96RL13200

EDT/ECN: 623484

Org Code: $\$ 1400$

B\&R Code:

UC: 721

Charge Code: CACN 106966 COA BAl0

Total Pages: 17

Key Words: low-activity waste, Phase 1

Abstract: This white paper evaluates the feasibility of cleaning tank 241-AP-108 for storage of pretreated low-activity waste. The maximum allowable heel inventories for ${ }^{90} \mathrm{Sr},{ }^{99} \mathrm{TC},{ }^{137} \mathrm{Cs}$, and TRU are established. Cesium-137 was found to be the limiting radionuclide for tank 241-AP-108 cleanout. Equipment requirements for cleanout are identified and risks associated with extended storage of pretreated lowactivity waste are discussed.

This evaluation assumes that tank 241-AP-108 will be used for storage of pretreated low-activity waste from tanks 241-AZ-101 and 241-AZ-102 in accordance with the 1996 Tank Waste Remediation System Privatization Contract with BNFL Inc. Alternatives are currently under development that would not require this storage function. This document is being issued to capture the work performed to date.

TRADEMARK DISCLAIMER. Reference herein to any specific comercial product, process, or service by trade name, trademark, manufacturer, or otherwise, does not necessarily constitute or imply its endorsement, recommendation, or favoring by the United States Government or any agency thereof or its contractors or subcontractors.

Printed in the United States of America. To obtain copies of this document, contact: Document Control Services, P.O. Box 950, Mailstop H6-08, Richland WA 99352, Phone (509) 372-2420;

Fax (509) $376-4989$.
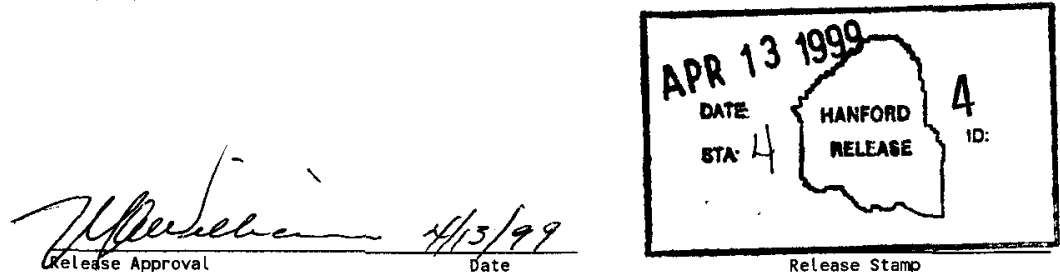

Release Stamo

Approved for Public Release 
HNF-4272

Revision 0

\title{
WHITE PAPER:
}

\section{CLEANOUT OF TANK 241-AP-108 FOR STORAGE OF PHASE 1 PRETREATED \\ LOW-ACTIVITY WASTE}

\author{
April 1999 \\ D. E. Place \\ COGEMA Engineering \\ Richland, Washington \\ Prepared for \\ U.S. Department of Energy \\ Richland, Washington
}


HNF-4272

Revision 0

This page intentionally left blank. 
HNF-4272

Revision 0

\section{CONTENTS}

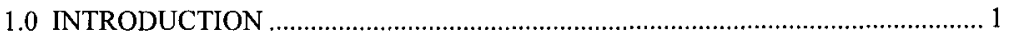

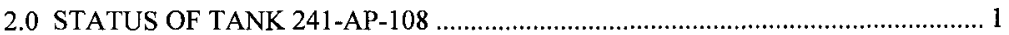

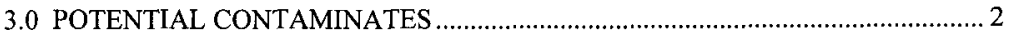

4.0 DEGREE OF DECONTAMINATION REQUIRED ........................................ 3

5.0 TANK 241-AP-108 CLEANOUT SCENARIO ............................................. 5

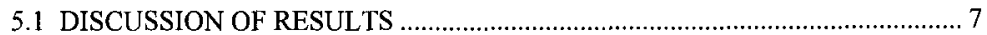

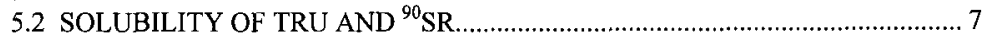

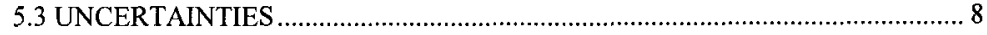

6.0 RISKS OF CONTAMINATING PRETREATED LOW-ACTIVITY WASTE ........ 9

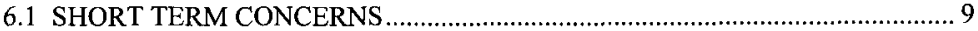

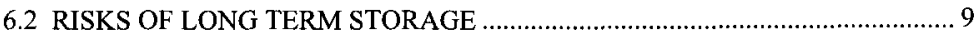

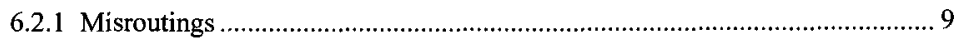

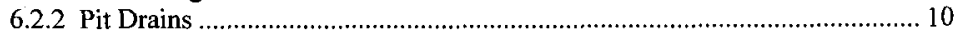

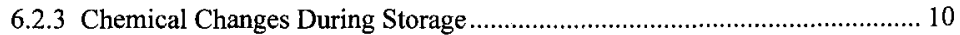

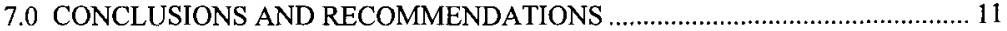

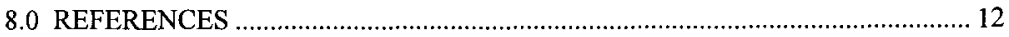

\section{LIST OF TABLES}

Table 1. Waste Receipt Summary for Tank 241-AP-108....................................... 2

Table 2. Waste Radionuclide Concentrations And Specification Limits. ....................... 3

Table 3. Specifications For Low-Activity Waste Glass and Pretreated Low-Activity Waste Feed............................................................................................. 4

Table 4. Low-Activity Waste Feed Concentrations To Meet Disposal Limits (Ci/L) ...... 4

Table 5. Maximum Allowable Radionuclide Inventories for Low-Activity Waste. ......... 5 
HNF-4272

Revision 0

\section{LIST OF TERMS}

DOE

DST

ICD

LAW

PUREX

TOC

TRU
U.S. Department of Energy

Double-shell tank

Interface Control Document

Low-activity waste

Plutonium-uranium extraction

Total organic carbon

Transuranic 
HNF-4272

Revision 0

\section{WHITE PAPER:}

\section{CLEANOUT OF TANK 241-AP-108 FOR STORAGE OF PHASE 1 PRETREATED LOW-ACTIVITY WASTE}

\subsection{INTRODUCTION}

The Project Hanford Management Contractors will, on behalf of the U.S. Department of Energy (DOE), deliver high-level wastes from tanks 241-AZ-101 and 241-AZ-102 to BNFL Inc. for treatment per Interface Control Document (ICD) $20 \mathrm{High}$ Level Waste Feed. BNFL Inc. will return a pretreated Low-Activity Waste (LAW) feed resulting from the treatment of the $\mathrm{HLW}$ feed per ICD 24, Pretreated Low-Activity Waste. Current planning is to receive, segregate, and store the pretreated LAW in tank 241-AP-108. Four hundred (400) units of the pretreated LAW will be returned to BNFL Inc. to demonstrate Envelope B vitrification as the last LAW feed in Phase 1 (DOE-RL 1996).

Dilute complexed waste is currently stored in tank 241-AP-108. Additional dilute complexed and/or dilute non-complexed waste may be received and stored in tank 241-AP-108 prior to storage of pretreated LAW (Boston 1998). The dilute wastes meet chemical specifications for LAW feed (DOE-RL 1996, Specification 7), but the ${ }^{90} \mathrm{Sr}$, ${ }^{99} \mathrm{Tc}$, and ${ }^{137} \mathrm{Cs}$ concentrations (curies per mole sodium) exceed the Specification 11 limits for the pretreated LAW. Mixing of the 241-AP-108 waste heel with the pretreated LAW will result in some degradation of product quality. The issue becomes one of how much degradation is allowable and, therefore, how well does tank 241-AP-108 need to be flushed prior to storage of pretreated LAW. Additionally, the risks of long term storage of pretreated LAW in 241-AP-108 due to potential waste transfer misroutings need to be evaluated, and the equipment to carry out the mission needs to be identified.

This study assumes that the pretreated LAW must be returned as a feed suitable for LAW vitrification without further treatment.

\subsection{STATUS OF TANK 241-AP-108}

Tank 241-AP-108 was placed in service in 1986, and is one of the newer Hanford double-shell tanks (DSTs). Waste transaction records (Agnew et al. 1997) indicate that radioactive waste was not stored in 241-AP-108 until the first quarter of 1990. Tank 241-AP-108 has received only relatively dilute wastes over its service life (no evaporator concentrate or sludge). Wastes receipts are summarized in Table 1. 
HNF-4272

Revision 0

Table 1. Waste Receipt Summary for Tank 241-AP-108.

\begin{tabular}{|l|l|}
\hline Year & \multicolumn{1}{|c|}{ Waste types received } \\
\hline 1990 & PUREX Ammonia Scrubber Waste (condensate) \\
\hline 1991 & PUREX Low-Level Wastes (post operation dilute wastes) \\
\hline 1992 & PUREX Low-Level Wastes (post operation dilute wastes) \\
\hline 1994 & $\begin{array}{l}\text { B Plant Low-Level Wastes (from 241-AY-102); PUREX Low- } \\
\text { Level Wastes (decanted from 241-AW-105) }\end{array}$ \\
\hline 1996 & $\begin{array}{l}\text { B Plant organic decontamination waste (strontium-90 stripped } \\
\text { from stored B Plant solvent) } \\
\text { Dilute complexed waste (from 241-AN-106) }\end{array}$ \\
\hline 1997 & Dilute non-complexed waste (from 241-AP-106) \\
\hline 1999 &
\end{tabular}

PUREX = Plutonium-uranium extraction.

The Plutonium Inventory Database (LMHC 1999a) indicates that tank 241-AP-108 has never contained more than 44.2 grams of plutonium (equivalent to approximately $3 \mathrm{Ci}$ of alpha radioactivity contained in the $4.3 \mathrm{E}+06 \mathrm{~L}$ of solution). This is consistent with a soluble liquid-phase plutonium inventory, and tends to support the conclusion 241-AP-108 has received no wastes containing significant insoluble materials.

\subsection{POTENTIAL CONTAMINATES}

The liquid waste stored in tank 241-A-101 was selected as representative of dilute complexed and non-complexed wastes that would be stored in tank 241-AP-108 prior to storage of pretreated LAW. Additionally, the composition of the waste stored in tank 241-AP-108 as of December 1998 is an important indicator of the initial radionuclide contamination present. Both the liquid wastes in tanks 241-A-101 and in 241-AP-108 (waste transfers altered the tank 241-AP-108 composition in January 1999) are chemically compatible with the Specification 7 for Envelope B feed based on analyses of 1996-1997 samples. The mercury concentration was not measured for either tank; however, best-basis inventory estimates indicate that there is no appreciable mercury in either tank (this should be confirmed by sample analysis). Given the large sodium inventory of pretreated LAW, it is extremely unlikely that the chemical elements present in the tank 241-AP-108 waste heel would affect compliance with Specification 7.

Radionuclides were assumed to be subject to Specification 11 for pretreated LAW (DOE-RL 1996) for purposes of this initial screening. The ratios of ${ }^{90} \mathrm{Sr},{ }^{99} \mathrm{Tc}$, and ${ }^{137} \mathrm{Cs}$ to sodium (Curies/mole sodium) for both 241-A-101 and 241-AP-108 are higher than the Specification 11 limit for pretreated LAW as shown in Table 2. 
$\mathrm{HNF}-4272$

Revision 0

Table 2. Waste Radionuclide Concentrations And Specification Limits.

\begin{tabular}{|c|c|c|c|}
\hline Radionuclide & $\begin{array}{c}241-\mathrm{AP}-108 \\
\text { Radionuclide Ratio } \\
\text { to Sodium } \\
\text { (Ci/mole Na) }\end{array}$ & $\begin{array}{c}241-\mathrm{A}-101 \\
\text { Radionuclide } \\
\text { Ratio to Sodium } \\
\text { (Ci/mole Na) }\end{array}$ & $\begin{array}{c}\text { Specification 11 } \\
\text { Limit } \\
\text { (Ci/mole Na) }\end{array}$ \\
\hline${ }^{90} \mathrm{Sr}$ & $9.5 \mathrm{E}-05$ & $8.05 \mathrm{E}-06$ & $5.0 \mathrm{E}-06$ \\
\hline${ }^{9} \mathrm{Tc}^{2}$ & $6.5 \mathrm{E}-06$ & $3.5 \mathrm{E}-05$ & $5.0 \mathrm{E}-06$ \\
\hline${ }^{137} \mathrm{Cs}$ & $2.6 \mathrm{E}-02$ & $3.9 \mathrm{E}-02$ & $1.5 \mathrm{E}-04$ \\
\hline $\mathrm{TRU}^{3}$ & $1.4 \mathrm{E}-10$ & $<6.4 \mathrm{E}-08$ & $1.2 \mathrm{E}-05$ \\
\hline
\end{tabular}

'Composition based on October 1997 samples. These concentrations are no longer entirely representative of the tank contents due to recent mixing with 241-AP-106 liquid wastes.

${ }^{2}$ Not analyzed, ${ }^{99} \mathrm{Tc}$ estimated from best-basis inventories for tanks 241-AP-108 and 241-A-101.

${ }^{3}$ Estimated as the sum of ${ }^{241} \mathrm{Am}$ and ${ }^{239 / 240} \mathrm{Pu}$, which comprise approximately $97 \%$ of TRU alpha decay radioactivity.

Any residual heel of tank 241-A-101 or 241-AP-108 liquid wastes will detract from the quality of the stored pretreated LAW because of high ${ }^{90} \mathrm{Sr},{ }^{99} \mathrm{Tc}$ and ${ }^{137} \mathrm{Cs}$ to sodium ratios. The degree to which the pretreated LAW will be contaminated with additional radionuclides depends on how rigorously the tank is flushed to dilute the waste heel.

\subsection{DEGREE OF DECONTAMINATION REQUIRED}

The acceptability of the radionuclide concentrations in the LAW feed to vitrification is determined from the ability to meet the product specifications for LAW glass without reducing waste loading $\left(\mathrm{w} t \% \mathrm{Na}_{2} \mathrm{O}\right)$ below that required by the chemical composition of the glass. LAW glass is limited to the concentrations shown in Table 3 (DOE-RL 1996, Specification 2). Additionally, the pretreated LAW feed returned for storage in tank 241-AP-108 must meet the Specification 11 limits given in Table 3 (DOE-RL 1996). 
Table 3. Specifications For Low-Activity Waste Glass and Pretreated Low-Activity Waste Feed.

\begin{tabular}{|c|c|c|}
\hline Radionuclide & $\begin{array}{c}\text { LAW Glass } \\
\text { Specification } 2 \\
\left(\mathrm{Ci}^{3}\right)\end{array}$ & $\begin{array}{c}\text { Pretreated LAW } \\
\text { Specification } 11 \\
(\mathrm{Ci} / \text { mole Na })\end{array}$ \\
\hline${ }^{157} \mathrm{Cs}$ & 3 & $1.5 \mathrm{E}-04$ \\
\hline${ }^{99} \mathrm{Tc}$ & 0.1 & $5.0 \mathrm{E}-06$ \\
\hline${ }^{90} \mathrm{Sr}$ & 20 & $5.0 \mathrm{E}-06$ \\
\hline $\mathrm{TRU}^{1}$ & 0.265 & $1.2 \mathrm{E}-05$ \\
\hline
\end{tabular}

LAW = Low-activity waste

${ }^{\mathrm{I}}$ Transuranic radionuclides as defined in 10CFR 61.55.

The radionuclide concentrations allowable in the LAW feed are inversely proportional to the waste loading in the LAW glass (represented as wt $\% \mathrm{Na}_{2} \mathrm{O}$ ). The range of waste loading considered is $6 \mathrm{wt} \% \mathrm{Na}_{2} \mathrm{O}$ (minimum specified for Envelope $\mathrm{B}$ in DOE-RL 1996, Specification 2), and $20 \mathrm{wt} \% \mathrm{Na}_{2} \mathrm{O}$, which is considered the upper technical limit for this waste form with ideal feed compositions. Higher waste loading will require a more complete clean out of AP-108 as shown in Table 4. These concentrations were derived from the Specification 2 radionuclide limits and the feed volume needed to produce a cubic meter of glass.

Table 4. Low-Activity Waste Feed Concentrations To Meet Disposal Limits $(\mathrm{Ci} / \mathrm{L})$.

\begin{tabular}{|c|c|c|c|c|c|}
\hline $\mathrm{Wt} \% \mathrm{Na} 2 \mathrm{O}$ & $6 \%$ & $7.5 \%$ & $10 \%$ & $15 \%$ & $20 \%$ \\
\hline${ }^{137} \mathrm{Cs}$ & $4.51 \mathrm{E}-03$ & $3.61 \mathrm{E}-03$ & $2.71 \mathrm{E}-03$ & $1.80 \mathrm{E}-03$ & $1.35 \mathrm{E}-03$ \\
\hline${ }^{99} \mathrm{Tc}$ & $1.50 \mathrm{E}-04$ & $1.20 \mathrm{E}-04$ & $9.02 \mathrm{E}-05$ & $6.01 \mathrm{E}-05$ & $4.51 \mathrm{E}-05$ \\
\hline${ }^{90} \mathrm{Sr}$ & $3.01 \mathrm{E}-02$ & $2.41 \mathrm{E}-02$ & $1.80 \mathrm{E}-02$ & $1.20 \mathrm{E}-02$ & $9.02 \mathrm{E}-03$ \\
\hline $\mathrm{TRU}$ & $3.98 \mathrm{E}-04$ & $3.19 \mathrm{E}-04$ & $2.39 \mathrm{E}-04$ & $1.59 \mathrm{E}-04$ & $1.20 \mathrm{E}-04$ \\
\hline $\begin{array}{c}\text { Feed volume }\left(\mathrm{L} / \mathrm{m}^{3}\right. \\
\text { glass) }\end{array}$ & 665 & 831 & 1,108 & 1,663 & 2,217 \\
\hline
\end{tabular}

The allowable contamination in the tank $241-\mathrm{AP}-108$ waste heel for ${ }^{137} \mathrm{Cs},{ }^{99} \mathrm{Tc}$, ${ }^{90} \mathrm{Sr}$, and TRU is determined from the difference in concentrations between the pretreated LAW delivered by BNFL Inc. and that needed to meet the LAW glass disposal limits. The maximum allowable radionuclide inventories are provided for LAW disposal and for the tank 241-AP-108 waste heel in Table 5 as a function of waste loading assuming a minimum of $2.4 \mathrm{E}+07$ moles of waste sodium in the pretreated LAW and a sodium concentration of 7.7 molar (DeLozier 1998). The corresponding minimum waste volume is $3.12 \mathrm{E}+06 \mathrm{~L}$. 
HNF-4272

Revision 0

Table 5. Maximum Allowable Radionuclide Inventories for Low-Activity Waste.

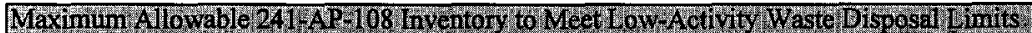
(Cures)

\begin{tabular}{|c|c|c|c|c|c|}
\hline $\mathrm{Wt} \% \mathrm{Na}_{2} \mathrm{O}$ & $6 \%$ & $7.5 \%$ & $10 \%$ & $15 \%$ & $20 \%$ \\
\hline${ }^{137} \mathrm{Cs}$ & $1.41 \mathrm{E}+04$ & $1.12 \mathrm{E}+04$ & $8.44 \mathrm{E}+03$ & $5.62 \mathrm{E}+03$ & $4.22 \mathrm{E}+03$ \\
\hline${ }^{99} \mathrm{Tc}$ & $4.69 \mathrm{E}+02$ & $3.75 \mathrm{E}+02$ & $2.81 \mathrm{E}+02$ & $1.87 \mathrm{E}+02$ & $1.41 \mathrm{E}+02$ \\
\hline${ }^{90} \mathrm{Sr}$ & $9.37 \mathrm{E}+04$ & $7.50 \mathrm{E}+04$ & $5.62 \mathrm{E}+04$ & $3.75 \mathrm{E}+04$ & $2.81 \mathrm{E}+04$ \\
\hline TRU & $1.24 \mathrm{E}+03$ & $9.94 \mathrm{E}+02$ & $7.45 \mathrm{E}+02$ & $4.97 \mathrm{E}+02$ & $3.73 \mathrm{E}+02$ \\
\hline
\end{tabular}

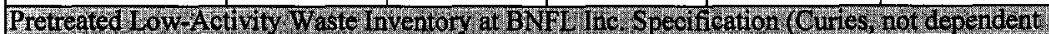
on Nar O waste loating

\begin{tabular}{|c|c|c|c|c|c|}
\hline $\mathrm{Wt} \% \mathrm{Na}_{2} \mathrm{O}$ & $6 \%$ & $7.5 \%$ & $10 \%$ & $15 \%$ & $20 \%$ \\
\hline${ }^{13} \mathrm{Cs}$ & $3.60 \mathrm{E}+03$ & $3.60 \overline{\mathrm{E}}+03$ & $3.60 \mathrm{E}+03$ & $3.60 \mathrm{E}+03$ & $3.60 \mathrm{E}+03$ \\
\hline${ }^{99} \mathrm{Tc}$ & $1.20 \mathrm{E}+02$ & $1.20 \mathrm{E}+02$ & $1.20 \mathrm{E}+02$ & $1.20 \mathrm{E}+02$ & $1.20 \mathrm{E}+02$ \\
\hline${ }^{90} \mathrm{Sr}$ & $1.20 \mathrm{E}+02$ & $1.20 \mathrm{E}+02$ & $1.20 \mathrm{E}+02$ & $1.20 \mathrm{E}+02$ & $1.20 \mathrm{E}+02$ \\
\hline TRU & $2.88 \mathrm{E}+02$ & $2.88 \mathrm{E}+02$ & $2.88 \mathrm{E}+02$ & $2.88 \mathrm{E}+02$ & $2.88 \mathrm{E}+02$ \\
\hline \multicolumn{6}{|c|}{ 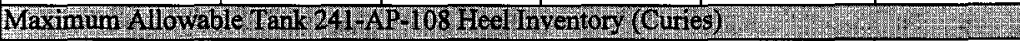 } \\
\hline $\mathrm{Wt} \% \mathrm{Na}_{2} \mathrm{O}$ & $6 \%$ & $7.5 \%$ & $10.0 \%$ & $15.0 \%$ & $20.0 \%$ \\
\hline${ }^{137} \mathrm{Cs}$ & $1.05 \mathrm{E}+04$ & $7.65 \mathrm{E}+03$ & $4.84 \mathrm{E}+03$ & $2.02 \mathrm{E}+03$ & $6.18 \mathrm{E}+02$ \\
\hline${ }^{99} \mathrm{Tc}$ & $3.49 \mathrm{E}+02$ & $2.55 \mathrm{E}+02$ & $1.61 \mathrm{E}+02$ & $6.75 \mathrm{E}+01$ & $2.06 \mathrm{E}+01$ \\
\hline${ }^{90} \mathrm{Sr}$ & $9.36 \mathrm{E}+04$ & $7.49 \mathrm{E}+04$ & $5.61 \mathrm{E}+04$ & $3.74 \mathrm{E}+04$ & $2.80 \mathrm{E}+04$ \\
\hline TRU & $9.54 \mathrm{E}+02$ & $7.06 \mathrm{E}+02$ & $4.57 \mathrm{E}+02$ & $2.09 \mathrm{E}+02$ & $8.46 \mathrm{E}+01$ \\
\hline
\end{tabular}

\subsection{TANK 241-AP-108 CLEANOUT SCENARIO}

A tank cleanout scenario was developed to further investigate the effect of waste loading on clean-out requirements. Several assumptions were required to evaluate the feasibility of tank 241-AP-108 clean out. The major assumptions include the following:

- The wetted surface of the tank was assumed to be coated with a dense salt cake to a depth of 1/20-in. The composition was assumed to be 241-A-101 liquid evaporated to dryness and compressed to the maximum theoretical density of sodium nitrate (the principle component).

- The pretreated LAW was assumed to contain a minimum of $2.4 \mathrm{E}+07$ moles of sodium (DeLozier 1998). This minimum sodium inventory assumes that BNFL Inc. does not dilute radionuclides by adding significant sodium ion during pretreatment processing. The sodium concentration of the pretreated LAW was assumed to be 7.7 molar in tank 241-AP-108 (DeLozier 1998).

- The minimum volume required for flushing of the tank sidewalls was assumed to be $7.57 \mathrm{E}+05 \mathrm{~L}(200,000 \mathrm{gal})$. 
HNF-4272

Revision 0

- The minimum volume for a subsequent heel dilution was assumed to be $3.785 \mathrm{E}+05 \mathrm{~L}(100,000 \mathrm{gal})$ based on liquid head requirements for operation of mixer pumps.

- A LAW glass density of $2.65 \mathrm{~kg} / \mathrm{L}$ was assumed (DeLozier 1998).

- The operational steps include: (1) flushing of the tank sidewalls, (2) pump-out of this flush to the minimum tank level of $15.2 \mathrm{~cm}$ (Kirkbride et al. 1997), (3) flushing of the tank bottom, and (4) pump-out of this final heel flush to the minimum tank level.

The results of this tank clean-out scenario based on the composition of the tank 241-A-101 liquid-phase waste are presented in Table 6.

Table 6. Tank 241-AP-108 Cleanout Scenario. (2 Sheets)

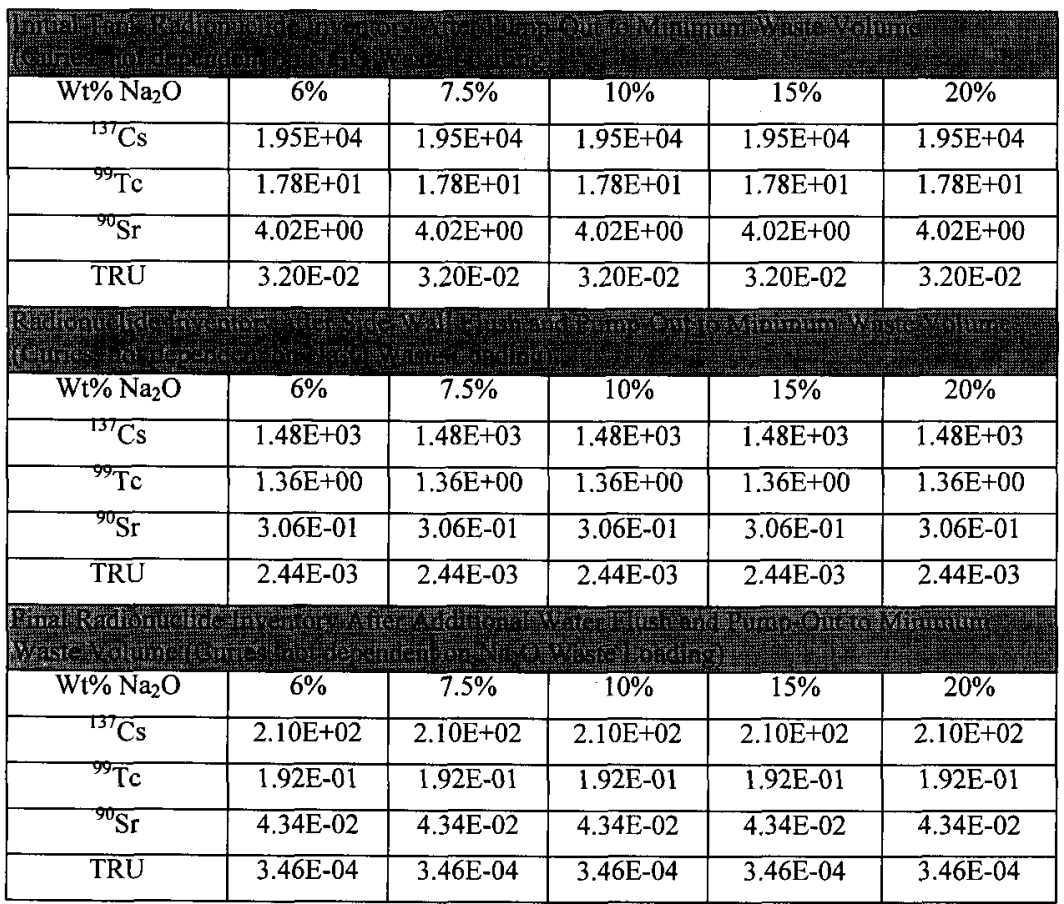


HNF-4272

Revision 0

Table 6. Tank 241-AP-108 Cleanout Scenario. (2 Sheets)

\begin{tabular}{|c|c|c|c|c|c|}
\hline $\mathrm{Wt} \% \mathrm{Na}_{2} \mathrm{O}$ & $6 \%$ & $7.5 \%$ & $10 \%$ & $15 \%$ & $20 \%$ \\
\hline${ }^{137} \mathrm{Cs}$ & $2.01 \mathrm{E}-02$ & $2.75 \mathrm{E}-02$ & $4.35 \mathrm{E}-02$ & $1.04 \mathrm{E}-01$ & $3.40 \mathrm{E}-01$ \\
\hline${ }^{99} \mathrm{Tc}$ & $5.52 \mathrm{E}-04$ & $7.55 \mathrm{E}-04$ & $1.19 \mathrm{E}-03$ & $2.85 \mathrm{E}-03$ & $9.34 \mathrm{E}-03$ \\
\hline${ }^{90} \mathrm{Sr}$ & $4.63 \mathrm{E}-07$ & $5.79 \mathrm{E}-07$ & $7.73 \mathrm{E}-07$ & $1.16 \mathrm{E}-06$ & $1.55 \mathrm{E}-06$ \\
\hline TRU & $3.62 \mathrm{E}-07$ & $4.90 \mathrm{E}-07$ & $7.56 \mathrm{E}-07$ & $1.66 \mathrm{E}-06$ & $4.09 \mathrm{E}-06$ \\
\hline
\end{tabular}

Clean out of tank 241-AP-108 by filling the entire tank with inhibited water and agitating with a mixer pump is considered a significantly less desirable clean-out method. The tank walls would likely not be cleaned as well, and a flush volume in excess of $4,200 \mathrm{~kL}$ would be generated. This flush volume would impact waste storage space, and may require more than one evaporator campaign.

\subsection{DISCUSSION OF RESULTS}

The limiting radionuclide for clean out of tank $241-\mathrm{AP}-108$ is ${ }^{137} \mathrm{Cs}$. The required removal of ${ }^{137} \mathrm{Cs}$ is more than a factor of ten higher than for ${ }^{99} \mathrm{Tc}$ and over a factor of ten thousand higher than for ${ }^{90} \mathrm{Sr}$ or transuranic (TRU) nuclides.

The clean-out requirements can be easily met for all waste loading with a total flush volume of $1.14 \mathrm{E}+06 \mathrm{~L}(300,000 \mathrm{gal})$. A safety factor of over thirty is achieved for ${ }^{137} \mathrm{Cs}$ at the most probable waste loading of $7.5 \mathrm{wt} \% \mathrm{Na}_{2} \mathrm{O}$ for Envelope B glass. For all cases but high waste loading ( $>15 \mathrm{wt} \% \mathrm{Na} 2 \mathrm{O}$ ), requirements for LAW feed could theoretically be met without the final heel flush.

The above tank clean-out scenario is intended only for proof of principal. Optimized flowsheets should be developed when the 241-AP-108 equipment is finalized, tank 241-AP-108 itself has been inspected, and the wastes that will be stored in 241-AP-108 prior to receipt of pretreated LAW have been identified and sampled.

\subsection{SOLUBILITY OF TRU AND ${ }^{90} \mathrm{SR}$}

The Tank Characterization Database (LMHC 1999b) was searched for high liquid-phase concentrations of TRU $\left({ }^{241} \mathrm{Am}\right.$ and $\left.{ }^{239 / 240} \mathrm{Pu}\right)$ and ${ }^{90} \mathrm{Sr}$. Concentrations of ${ }^{241} \mathrm{Am}$ and ${ }^{90} \mathrm{Sr}$ exceeding 50 percent of the maximum allowable for LAW feed as indicated in Table 4 were found only for tanks which also had high liquid phase Total Organic Carbon (TOC) concentrations (tanks 241-AN-102, 241-AN-107, 241-SY-101, 241-U-102 and 241-U-103). Similarly, ${ }^{239 / 240} \mathrm{Pu}$ concentrations exceeding 50 percent of the maximum TRU level were found only in tanks that were depleted in hydroxide ion (241-C-106 and 241-AY-102). Since neither of these conditions will be present during 
pretreated LAW storage, it is unlikely that a liquid phase can be created that is not suitable for LAW vitrification because of insoluble radionuclides. Even if the sizable safety margins for TRU and ${ }^{90} \mathrm{Sr}$, indicated in Table 6 , are exceeded, the supernate can be decanted as an acceptable LAW feed.

\subsection{UNCERTAINTIES}

The composition of the tank 241-A-101 liquid phase was assumed in this evaluation, however, the future service of tank 241-AP-108 tank is subject to uncertainty. Although the Operational Waste Volume Projection (Strode and Boyles 1998) indicates that tank 241-AP-108 will be the dilute complexed waste receiver for East Area, plans to use the tank for non-complexed dilute waste are being implemented by Tank Farm Operations. The difference in these waste types is inconsequential; however, tank clean out will be significantly more difficult if either evaporator concentrates (double-shell slurry feed) or sludge is transferred into tank 241-AP-108. Configuration control has been established for to limit tank 241-AP-108 wastes to dilute wastes containing no solid material (Boston 1998).

The 241-A-101 liquid-phase ${ }^{137} \mathrm{Cs}$ concentration of $0.365 \mathrm{Ci} / \mathrm{L}$ is typical for saltwell liquors and is appropriate for this evaluation. Mean liquid-phase ${ }^{137} \mathrm{Cs}$ concentrations for single-shell tanks are below $0.44 \mathrm{Ci}^{137} \mathrm{Cs} / \mathrm{L}$ (LMHC 1999b). The average liquid-phase ${ }^{137} \mathrm{Cs}$ concentration for tank 241-AX-101 (another 200 East Area tank containing a significant liquid inventory) is only 8 percent higher.

The ${ }^{99} \mathrm{Tc}$ concentrations for tanks 241-AP-108 and 241-A-101 were estimated from the best-basis inventories (LMHC 1999b) due to the lack of applicable sample data. This evaluation indicates that ${ }^{137} \mathrm{Cs}$ is the limiting radionuclide by more than a factor of ten; however, actual ${ }^{99} \mathrm{Tc}$ measurements should be made before large waste transfers into tank 241-AP-108.

The quantity and composition of solid material currently in tank 241-AP-108 or that might be added as the result of future waste transfers is unknown. Based on waste transaction records, it has been assumed that any solids material is a salt cake that coats the surfaces of the tank walls. Determination of the current or future tank 241-AP-108 radionuclide inventory is difficult, almost requiring a cleanout effort to establish an accurate base-line inventory. Video inspection of the tank walls and sludge measurement should conducted. The inspection and sludge measurement efforts are unlikely to provide quantitative data, but it is prudent to confirm that the tank 241-AP-108 salt cake or sludge inventories are consistent with that expected based on waste transfer history.

This evaluation assumes perfect mixing for tank heel dilutions (i.e., that the liquid or any minimal quantities of insoluble solids can be completely homogenized with the flush solution). The choice of cleanout equipment (mixer pumps or sluicing system) can affect the degree to which this assumption is valid, and could result in larger volumes of flush solution. 
HNF-4272

Revision 0

\subsection{RISKS OF CONTAMINATING PRETREATED LOW-ACTIVITY WASTE}

\subsection{SHORT TERM CONCERNS}

AP Farm tanks have not received wastes containing sludge, consequently little buildup of sludge in the waste lines of the AP Valve pit is expected. A more significant potential for cross-contamination is with the soluble radionuclides ${ }^{99} \mathrm{Tc}$ and ${ }^{137} \mathrm{Cs}$ left in the lines from other waste transfers. At least one staging transfer of LAW feed involving the AP Valve Pit will occur during the time that pretreated LAW is being received into tank 241-AP-108 (LAW feed from 241-AN-107). Additionally, periodic operation of the 242-A Evaporator may result in the transfer of salt slurries through the AP Valve Pit piping, and some salt well pumping may still be ongoing.

Water flushing of the transfer lines following such transfers would eliminate the potential for cross contaminating the pretreated LAW being returned from BNFL Inc. to 241-AP-108. However, it should be noted that only two ball valves (one 3-way and one 2 -way) prevent the misrouting of wastes with high ${ }^{137} \mathrm{Cs}$ and ${ }^{99} \mathrm{Tc}$ concentrations into tank 241-AP-108.

\subsection{RISKS OF LONG TERM STORAGE}

Pretreated LAW will be stored in tank 241-AP-108 for several years.

Approximately seven years will elapse between the initial receipt of pretreated LAW and the completion of the Phase 1 processing of 400 units of Envelope B material. Phase 1 will process less than 28 percent of the pretreated LAW, so storage will continue into Phase 2 processing. During the extended storage periods, the pretreated LAW will be at some risk of re-contamination.

\subsubsection{Misroutings}

The supernate transfer line associated with tank 241-AP-108 (SN-618) slopes to the tank, and can only be flushed in that direction. Any leakage past the two ball valves protecting 241-AP-108 will eventually reach the tank and contaminate the pretreated LAW despite any additional block valves located in the 241-AP-108 central pump pit.

The SN-618 line length is approximately $122.5 \mathrm{~m}$ (Carlson et al. 1998), with a resulting line volume of $583 \mathrm{~L}$ (154 gallons). A line volume of waste containing $0.8 \mathrm{Ci}$ ${ }^{137} \mathrm{Cs} / \mathrm{L}$ (highest concentration for any current DST) could, depending on clean-out efficiency, cause LAW disposal requirements to be exceeded at high waste loading (see Tables 5 and 6 ). However, there are adequate safety margins at a more probable $7.5 \mathrm{wt} \%$ $\mathrm{Na}_{2} \mathrm{O}$ waste loading for LAW glass. 
HNF-4272

Revision 0

The potential exists for misrouting of large volumes of waste solution to tank 241-AP-108 during the extended storage of the pretreated LAW product regardless of the levels of controls provided. The risk can minimized by providing an additional block valve in the 241-AP-108 central pump pit and removing the jumper to tank 241-AP-108 in the AP Tank Farm valve pit during extended periods when 241-AP-108 is not receiving or transferring pretreated LAW. As a worst case, the pretreated LAW would have to be reprocessed for insoluble solids removal and ${ }^{137} \mathrm{Cs}$ and ${ }^{99} \mathrm{Tc}$ ion exchange.

\subsubsection{Pit Drains}

The only valve or pump pit drains routed to tank 241-AP-108 are the drains from the central pump pit and the annulus pit for 241-AP-108 itself. In particular, the drains for the AP Tank Farm valve pit are routed to tank 241-AP-103. Consequently, there is little risk of re-contaminating the pretreated LAW product as the result of a line leak.

\subsubsection{Chemical Changes During Storage}

The hydroxide ion concentration of the pretreated LAW solution will be continuously reduced by adsorption of atmospheric carbon dioxide. The solubility of aluminum is dependent on the hydroxide ion concentration; consequently aluminum is expected to precipitate as gibsite, $\mathrm{Al}(\mathrm{OH})_{3}$. A preliminary estimate using Environmental Simulation Program (ESP, a commercial thermodynamic modeling software product licensed by OLI Systems Inc.) indicates that approximately $140 \mathrm{~L}$ ( $37 \mathrm{gal}$ ) of aluminum hydroxide will accumulate in tank 241-AP-108 during each year of storage based on absorption of 15 grams $\mathrm{CO}_{2} / \mathrm{hr}$ (Sathyanarayana 1994). During 20 years of storage, less than one-half inch of sludge would accumulate in the tank. There are three primary alternatives for dealing with this sludge:

1. Ignore this small volume of solids if the BNFL Inc. processes will tolerate this minimal solids loading.

2. Sodium hydroxide could be added to re-dissolve any precipitated aluminum if tank space permits. A mixer pump could then be used to suspend accumulated sludge, assuring reasonable reaction rates.

3. The supernate could be decanted from tank 241-AP-108 to BNFL Inc.

4. BNFL Inc. could filter the feed upon receipt from the PHMC. BNFL Inc. pretreatment equipment should otherwise be idle during this period because this is the last waste to be processed as part of Phase 1. BNFL Inc. could either dissolve the separated solids for inclusion in the LAW vitrification feed or return the solids to the underground tank system for inclusion in Phase 2 (this potential waste return is not currently addressed in the BNFL Inc. contract or in the interface control documents). 
HNF-4272

Revision 0

Regardless of the method selected, the precipitation of aluminum will not be a major obstacle in storage or subsequent processing of pretreated LAW.

\subsection{CONCLUSIONS AND RECOMMENDATIONS}

This white paper has evaluated the feasibility of cleaning tank 241-AP-108 for storage of pretreated LAW. Cesium- 137 has been found to be the limiting radionuclide. Equipment requirements for clean-out of tank 241-AP-108 include the following:

- Mixer pump or sluicing system for clean out of the tank bottom

- High-pressure spray or sluicing system for decontamination of tank walls.

- Transfer pump capable of removing liquid to the $15.2 \mathrm{~cm}(6-\mathrm{in}$.) level.

- System for make-up of corrosion-inhibited flush solution (dilute $\mathrm{NaOH} / \mathrm{NaNO}_{2}$ ).

The controls established for wastes routed to 241-AP-108 (Boston 1998) need to be followed. Introduction of large quantities of sludge or evaporator concentrate would make the tank much more difficult to clean and likely would require substantially higher flush volumes. As an additional precaution, BNFL Inc. should not be allowed to add process chemicals that could complex either TRU or ${ }^{90} \mathrm{Sr}$ (additives containing organic materials currently require DOE permission per Specification 11 of the BNFL Inc. Contract). This would assure that the liquid phase would not exceed LAW disposal requirements for TRU or ${ }^{90} \mathrm{Sr}$.

Initial inspections of 241-AP-108 should be conducted to confirm that the tank condition is consistent with expectations. The inspection should include sludge level determinations, video inspection of the tank (especially the tank wall), and measurements of the contamination on the tank wall (direct and smear).

The ${ }^{99} \mathrm{Tc}$ concentrations for potential wastes routed through 241-AP-108 need to be measured to confirm that ${ }^{99} \mathrm{Tc}$ removal is less restrictive than ${ }^{337} \mathrm{Cs}$. Best-basis inventory estimates have been used in this white paper due to a lack of directly applicable analytical data.

The valve configuration between the AP Tank Farm Valve Pit and tank 241-AP-108 needs to be improved to reduce the potential for misroutings. The two-way ball valve in the AP Tank Farm Valve Pit should be replaced with a valve having more positive shut-off characteristics. The jumper allowing transfer to tank 241-AP-108 should be completely removed when 241-AP-108 will be inactive for several years (i.e., not receiving pretreated LAW or transferring this product to BNFL Inc.). 
HNF-4272

Revision 0

\subsection{REFERENCES}

Agnew, S. F., R. A. Corbin, T. B. Duran, K. A. Jurgensen, T. P. Ortiz, and B. L. Young, 1997, Waste Status and Transaction Record Summary (WSTRS Rev. 4), LA-UR-97-311, Rev. 0, Los Alamos National Laboratory, Los Alamos, New Mexico.

Boston, H. L., 1998, Configuration Control of Tank Waste Compositions, Letter 8700098-086 to M. A. Payne, November 12, Lockheed Martin Hanford Company, Richland, Washington.

Carlson, A. B., W. L. Willis, and T. R. Benegas (COGEMA), 1998, Evaluation of 241-AZ Tank Farm Supporting Phase 1 Privatization Waste Feed Delivery, HNF-2941 Rev. 0, Numatec Hanford Corporation, Richland Washington.

DeLozier, M. P., 1998, Subcontract Number 80232764-9-K001 Evaluation of Tank Waste Disposal Alternatives within Privatization, Letter LMHC-9854671A R1 to

A. M. Umek (FDHC), June 15, Lockheed Martin Hanford Corporation, Richland, Washington.

DOE-RL, 1996, TWRS Privatization (BNFL), Contract DE-AC06-96RL13308, (September) (Amendment A006 August 24, 1998), U. S. Department of Energy Richland Operations Office, Richland Washington.

Kirkbride, R. A., G. K. Allen, P. J. Certa, A. F. Manuel, R. M. Orme, L. W. Shelton, E. J. Slaathaug, R. S. Wittman, and G. T. MacLean, and D. L. Penwell SESC), 1997, Tank Waste Remediation System Operation and Utilization Plan, HNF-SD-WM-SP-012, Rev. 0A, Numatec Hanford Corporation, Richland, Washington.

LMHC, 1999a, Plutonium Inventory Database, Hanford Information System Identification HISI-11350, Lockheed Martin Hanford Corporation, Richland Washington.

LMHC, 1999b, Tank Characterization Database, Internet at http://twins.pnl.gov:8001/TCD/main.html, Lockheed Martin Hanford Corporation, Richland Washington.

Sathyanarayana, K., 1994, Estimation of Potential $\mathrm{CO}_{2}$ Absorption Rate in Aging Waste Tank, Internal Memo 23230-94-KS-010 to G. T. MacLean, Westinghouse Hanford Company, Richland, Washington.

Strode, J. N., and V. C. Boyles, 1998, Operational Waste Volume Projection, HNF-SD-WM-ER-029, Rev. 24, Lockheed Martin Hanford Corporation, Richland, Washington. 


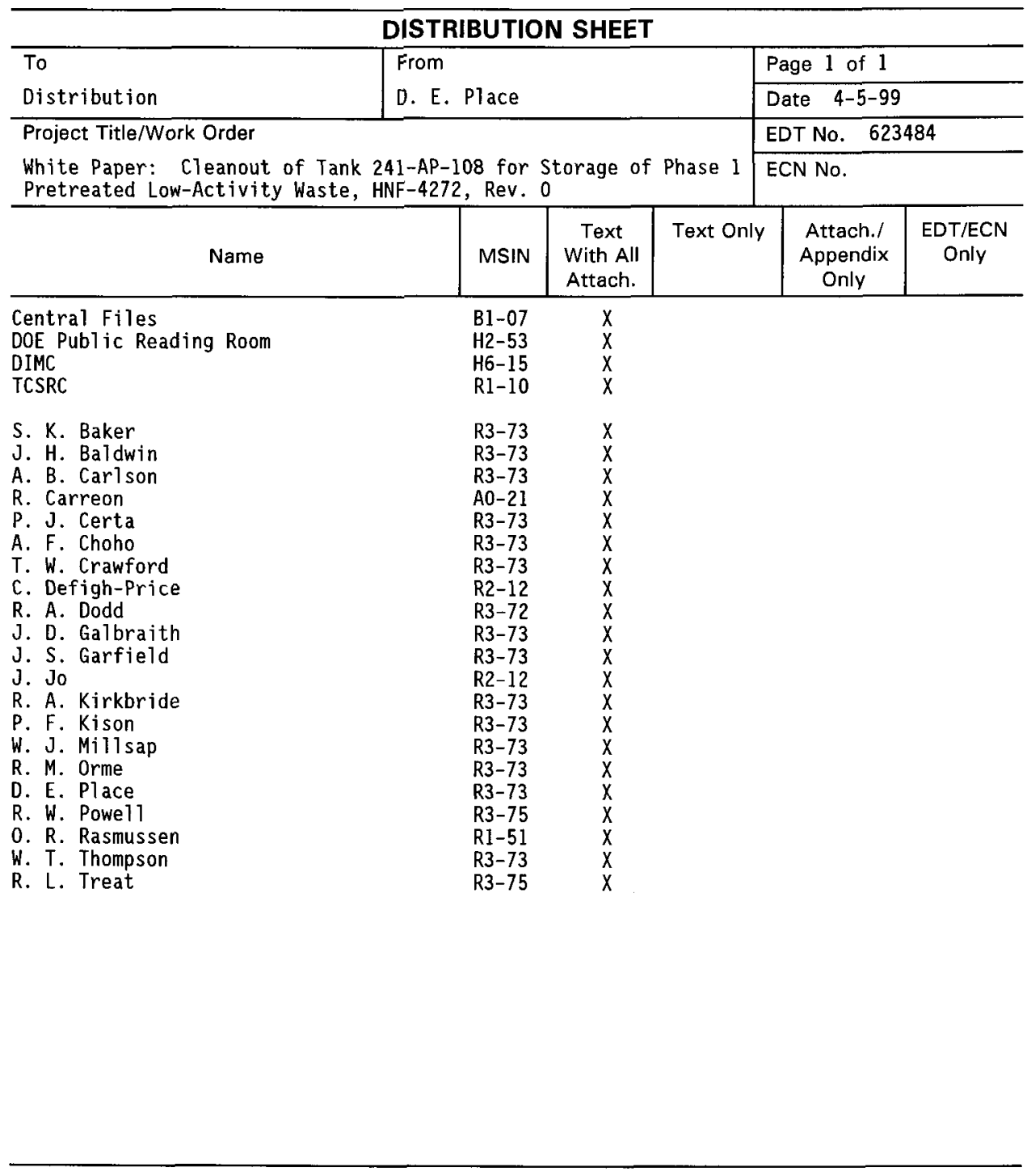

